\title{
Soil properties as indicators of treeline dynamics in relation to anthropogenic pressure and climate change
}

\author{
M. Cristina Moscatelli ${ }^{1}$, Eleonora Bonifacio ${ }^{2}$, Tommaso Chiti ${ }^{1}$, Pavel Cudlín ${ }^{3}$, \\ Lucian Dinca ${ }^{4}$, Erika Gömöryova ${ }^{5}$, Stefano Grego ${ }^{6}$, Nicola La Porta ${ }^{7}$, \\ Leszek Karlinski ${ }^{8}$, Guido Pellis ${ }^{1}$, Maria Rudawska ${ }^{8}$, Andrea Squartini ${ }^{9}$, \\ Miglena Zhiyanski ${ }^{10}$, Gabriele Broll ${ }^{11, *}$
}

\footnotetext{
${ }^{1}$ Department of Innovation in Biological, Agrofood and Forest systems (DIBAF), University of Tuscia, Viterbo, Italy ${ }^{2}$ Department of Agricultural, Forest and Food Sciences (DISAFA), University of Torino, largo P. Braccini 2, 10095 Grugliasco, Italy

${ }^{3}$ Global Change Research Centre, Academy of Sciences of the Czech Republic, Lipová 1789/9, České Budějovice 37005 , Czech Republic

${ }^{4}$ National Forest Research-Development Institute I.N.C.D.S. Brasov, 13 Closca St., 500030 Brasov, Romania

${ }^{5}$ Technical University in Zvolen, Faculty of Forestry, T. G. Masaryka 24, 96053 Zvolen, Slovakia

${ }^{6}$ Department of Science and Technology for Agriculture, Forestry, Nature and Energy (DAFNE), Tuscia University, Viterbo, Italy

${ }^{7}$ Research and Innovation Centre, Fondazione Edmund Mach (FEM) and MOUNTFOR Project Centre, European Forest Institute, Via E. Mach 1, 38010 San Michele all Adige (Trento), Italy

${ }^{8}$ Institute of Dendrology, ul. Parkowa 5, 62-035 Kórnik, Poland

${ }^{9}$ Department of Agricultural Biotechnology, University of Padua, Agripolis, Viale dell 'Università 16, 35020 Legnaro, Padua, Italy

${ }^{10}$ Forest Research Institute - Bulgarian Academy of Sciences, 132 ‘Kl. Ohridski' Blvd., 1756 Sofia, Bulgaria

${ }^{11}$ Institute of Geography, University of Osnabrueck, Seminarstr. 19, 49074 Osnabrueck, Germany
}

\begin{abstract}
Mountain forests, treeline ecotones included, provide numerous ecosystem services. However, different drivers heavily impact the treeline areas, in particular anthropogenic pressure and climate change. Any change affecting the aboveground portion of terrestrial ecosystems automatically influences their belowground part, i.e. soil and soil organisms. Therefore, the focus of the present paper is on the soil resource that provides multiple ecosystem services, such as carbon storage, water filtration, food and biomass provisioning, biodiversity, maintenance, etc. Soil physical, chemical, and biological properties can be very helpful as indicators of ecosystem services in mountain regions. A selection and integration of appropriate indicators of soil quality is thus needed for soil monitoring and assessment in treeline areas. In this paper, results of case studies from mountain regions in Bulgaria, the Czech Republic, Italy, Romania, and Slovakia are presented. From these studies, it emerges that soil organic matter (content and quality), $\mathrm{pH}$, and microbial parameters show significant changes in response to anthropogenic pressures and/or climate change. These indicators of soil quality, either in the short- or in the long-term, can thus be used as reliable and sensitive tools for monitoring actions. However, it is advisable to integrate this basic set with additional indicators that can be further selected in relation to specific conditions, such as geographical area, lithological substrate, land use, and management practices.
\end{abstract}

KEY WORDS: Ecosystem services $\cdot$ Forest resilience $\cdot$ Mountains

\section{INTRODUCTION}

Treeline ecotones are natural boundaries where plant species, plant productivity, and fauna change

${ }^{*}$ Corresponding author: gabriele.broll@uni-osnabrueck.de under the influence of global climate change along a small altitudinal gradient and at short distance (Broll \& Keplin 2005, Holtmeier 2009, Körner 2012). Mountain forests, and thus treeline ecotones, provide sev-

(C) The authors 2017. Open Access under Creative Commons by Attribution Licence. Use, distribution and reproduction are unrestricted. Authors and original publication must be credited. 
eral ecosystem services, such as hydrological regulation and protection against avalanches and erosion. The upper treeline ecotone plays an important role as a potential indicator of environmental change. However, different drivers heavily impact treeline ecosystems. Among these are climate change and anthropogenic pressures such as overgrazing, abandonment, or reforestation of formerly grazed areas (e. g. Broll 2000, Holtmeier \& Broll 2005, 2007, Palombo et al. 2014, Wieser et al. 2014). Climate change resulting in lasting drought periods, strong winds and snow storms, or modification of the snow regime, may potentially lead to physiological weakening, damage, or even destruction of forest stands, especially at the treeline (Holtmeier \& Broll 2007, 2010). The soil in these areas may be affected in its structure, capacity to store carbon, cycling of mineral nutrients, and ultimately in the diversity of soil organisms. All these natural and anthropogenic disturbances (e.g. land use change, pollution, management practices), alone or combined in synergistic processes, induce changes that may impact the resilience and sustainability of these fragile ecosystems. The characteristics and properties of soils in treeline ecotones depend on specific climatic conditions and type of vegetation, as well as on the different land uses, silviculture, and management practices (Raev et al. 2011).

There is a strong interaction between plant cover and soil condition. Any change affecting the aboveground portion of terrestrial ecosystems automatically impacts the soil, and its complex multiphase system and biological network (Ponge 2013). Major changes affecting trees and vegetation, in general, may be expected to impact not only the soil organic matter content but also the entire soil profile (Bonifacio et al. 2008a). The opposite also occurs: e.g. root growth and seedling density are strongly influenced by the physical and chemical properties of the soil in terms of soil organic matter, nitrogen content, $\mathrm{pH}$, temperature, porosity, structure, and moisture, which can change in response to natural and/or anthropogenic disturbances (land use changes, climate change) (e.g. Anschlag et al. 2008). Soil plays an important role in these ecosystems, and deserves special attention when studying the vulnerability of treeline ecotones. Therefore, a strong and increasing demand for effective monitoring of soils at local, regional and national scales is required. The soil security concept (McBratney et al. 2012) introduces a soil-centric framework that can be used as the basis of policies aimed to achieve ecological and human sustainable development.

\section{SOIL INDICATORS}

Soil quality indicators refer to measurable soil attributes that influence the capacity of soil to sustain crop production and perform several other environmental functions (Arshad \& Martin 2002). The term soil 'indicators' was introduced together with the concepts of soil quality and soil health by Doran \& Parkin (1994). However, there is still an ongoing scientific debate and lack of a shared consensus on the concepts of soil quality and soil health (Gil-Sotres et al. 2005) and on which properties of soils may be most appropriately monitored. As for the first issue, the term 'quality' seems to be more related to an anthropocentric view of soil, while the term 'health' encompasses soil functions and is focused on its ecological attributes (Gil-Sotres et al. 2005, Janvier et al. 2007). The difficulty in deciding which of the many properties of soil to choose is partly due to the wide range of goods and services that soils provide in diverse contexts, but also to their chemical, physical, and biological complexity linked to the strict interactions among the solid, liquid, and gaseous phases. There is currently a great variety of indicators that can potentially be used to monitor soil quality. It is, therefore, important and recommended to focus on those indicators that can act as early warning of any degradation process affecting the soil resource.

Among established soil chemical parameters like soil $\mathrm{pH}$, soil organic matter (SOM) is the most important integrative indicator of soil quality. A strong interrelationship between SOM and other indicators such as soil aggregate stability, infiltration, bulk density, nutrient availability, microbial biomass, and activity has been widely demonstrated (e.g. Carletti et al. 2009); therefore several other soil characteristics can be inferred through SOM assessment. In particular, in relation to climate change, it is fundamental to evaluate soil carbon (C) sink potential. Therefore, the level of recalcitrance-the physical and chemical protection of SOM-is the focus of recent studies devoted to $\mathrm{C}$ cycling under global climate change (Schmidt et al. 2011, Cotrufo et al. 2015). In recent years, the attention of research into SOM has focused more on its quality than on its quantity, showing that this aspect is more relevant for ecological issues concerning $\mathrm{C}$ storage and $\mathrm{C}$ cycling in general (Rovira \& Vallejo 2002, von Lutzow et al. 2007). Moreover, SOM content and quality are strictly related to soil stability and erosion processes, which are of major importance in mountainous areas (Egli \& Poulenard 2017). 
Soil biological properties can be successfully used as indicators of soil quality in addition to physicalchemical features (Ritz et al. 2009). Microorganisms are definitively the actors of almost all processes occurring in soils. Soil microbial communities enable the healthy functioning of terrestrial ecosystems through diversity in terms of community structure and/or activity (Nielsen \& Winding 2002). Soil microbial processes include decomposition of organic residues, transformation of SOM, mineralization and immobilization of nutrients, and formation and stabilization of soil aggregates (Nannipieri et al. 2003). In forest ecosystems, many natural (e.g. climate) and anthropogenic disturbances (land use change, pollution, management practices) may modify soil microbial communities in terms of structure and functions (Moscatelli et al. 2007). Climate and land use changes may affect the microorganism-soil-plant root system, modifying many physical, chemical, and biological soil properties which can represent critical features of treeline ecotones. Changes in microbial populations, community structure, activity, and diversity have proved to be the most sensitive and reliable bioindicators in the monitoring of soil health and quality (Paz-Ferreiro \& Fu 2016). Any change in plant cover modifies litter quality and quantity, alters root exudation, and changes the microclimate, and may lastingly affect soil biota and influence microbial community diversity. Microbial functional diversity was recently used to describe soil development under different moisture regimes and at different altitudes in mountain ecosystems. As soil evolution proceeded through an increasing niche separation, an interesting link between microbial functions and soil development was found (Marinari et al. 2013).

A healthy soil is defined as a stable system with high levels of biological diversity and activity, internal nutrient cycling, and resilience to disturbance. Soil biota (biomass, activity, and diversity) are primarily responsible for soil health and suppression of soil-borne pathogens (due to higher antagonism). Microbial fluctuations after a disturbance would dampen more quickly in a healthy than in a chronically damaged and biologically impoverished soil. The resistance and resilience of microbial communities in response to a disturbance can be considered quantitative indicators for soil health (van Bruggen \& Semenov 2000). Due to this last, dynamic property of soil biota, using microbial properties as indicators of soil status in treeline ecotones can also take into account the resilience capacity of these ecosystems to face disturbances, as claimed in the SENSFOR concept note (Kyriazopoulos et al. 2014).
As far as is known, arctic and alpine vegetation of treeline regions are mycorrhizal (Haselwandter 2007) with several distinct mycorrhizal associations, such as arbuscular, ectomycorrhizal, ericoid, and dark septate fungi types. Mycorrhizal relationships are considered favorable, especially for plants in nutrient-stressed situations, and therefore may be particularly beneficial in treeline ecosystems characterized by harsh environmental condition like low temperatures, high rain or snowfall and low evaporation rates, nutrient-limited soils, and short-growing season (Haselwandter 2007, Schmidt et al. 2008). As a result, many alpine or tundra plants develop extensive root systems, often highly mycorrhizal, as the main route of nutrient supply to the host plants. Mycorrhizal fungi are also an important biotic factor in the survival of conifer seedlings under the stressful conditions of alpine or tundra habitats (Reithmeier \& Kernaghan 2013). Alpine treeline ecosystems with widely distributed coniferous trees and shrubs are the main reservoir of ectomycorrhizal fungi. Their contribution as a symbiont decreases with increasing altitude (Gardes \& Dahlberg 1996, Schmidt et al. 2008). In contrast to ectomycorrhizal fungi, ericoid symbionts dominate in heathlands and tend to increase root colonization at upper altitudes (Väre et al. 1997). Arbuscular mycorrhizas are ubiquitous in low alpine and arctic areas; however, their level of root colonization differs between species and habitats (Gardes \& Dahlberg 1996). Host species appears to be a main factor influencing the community composition of arbuscular fungi (Becklin et al. 2012). An important group of fungi, common and abundant among plants of the treeline ecotone, is dark septate fungi, although their ecological role is still not sufficiently recognized. Since the report of Gardes \& Dahlberg (1996), the number of studies exploring or characterizing fungal diversity in arctic and alpine ecosystems has gradually increased. It has been found that mycorrhizal diversity tends to be lower in arctic and alpine areas than in other regions, due to environmental constrains, dispersal barriers, and an increased number of facultative or non-mycorrhizal host species (e.g. Kernaghan \& Harper 2001). The observed lower fungal diversity correlates well with observations of lower fungal biomass in soils of mountain forests stands, reflected by specific biomarkers (phospholipid fatty acid and ergosterol concentration) or content of extramatrical mycelium of ectomycorrhizal fungi in soil (Karliński et al. 2015). The biomass of extramatrical mycelium is largely influenced by the community structure of ectomycorrhizal fungi associated with the forest trees (Ekblad 
et al. 2013), as different fungal species produce variable amounts of extramatrical mycelium, which builds a mycelial network in the soil and may have variable tolerance to natural and anthropogenic stress factors (Karliński \& Kieliszewska-Rokicka 2004). In contrast to the altitude gradient, seasonal fluctuations and changes in soil nutrient status play a significant role in microbial (including fungi) biomass and biodiversity of alpine and tundra forests (Buckeridge et al. 2013). Becklin et al. (2012) observed a stronger effect of host identity than habitat on the fungal community of alpine plant species. A high species diversity of fungi associated with alpine and arctic Dryas octopetala and a lack of influence of high altitude was demonstrated by Bjorbækmo et al. (2010). Schmidt et al. (2008) suggested that the altitudinal distributions of mycorrhizal fungi observed for European mountains do not necessarily apply to higher and drier mountains in other parts of the world. Thus, additional surveys spanning a greater number of sites, host species, and types of mycorrhiza are needed to fully understand the role of factors shaping the mycorrhizal community of the treeline ecotone.

The objective of this paper was therefore to identify reliable and strong indicators useful for monitoring soil properties in mountain forests and treeline ecotones, in particular. For this purpose, 7 case studies from mountains of different regions of Europe are presented to show the importance of soil characteristics as indicators of treeline dynamics in relation to anthropogenic pressures and/or climate change. When not specifically indicated, climatic and anthropogenic pressures were considered for their combined and/or synergic impact on soil properties (Oliver \& Morecroft 2014). Within the EU project SENSFOR, the discussion of soil indicators was integrated into the discussion of indicators for changes in the treeline ecotone in general (Broll et al. 2016).

\section{TREELINE ECOTONES AND SOIL INDICATORS}

Within the numerous services that forested soil performs in treeline areas, key ecosystem services were selected for the aims of this paper: (1) protection of the area below treeline, i.e. prevent shallow landslide, erosion, and flooding, (2) sequestering of carbon, i.e. maintaining the SOM content and quality, and (3) acting as habitat for plants, animals, and microorganisms, and maintaining a high biodiversity (Adhikari \& Hartemink 2016). Soil erosion, caused by landslide on steep slopes, represents a crucial problem affecting mountain soils, which are generally shallow, and their fertility is often concentrated in the uppermost layers (Stanchi et al. 2015, Egli \& Poulenard 2017). Therefore, following soil loss, erosion provokes a loss of fertility, reduced carbon storage capacity, and ultimately a reduced level of biodiversity above- and belowground.

Once key ecosystem services performed by soil have been identified, the correct soil indicators to be used in a monitoring action can be selected. In this context, a promising way to analyze the impact of human-environment interactions on ecosystem services seems to be the application of the DPSIR (Drivers, Pressure, State, Impact, Response) framework (Kyriazopoulos et al. 2014). In order to assess the sustainability of treeline ecotones, it is important to use indicators that identify specific pressures (P) and impacts (I) within ecosystems that can also be monitored for their capacity to tolerate disturbances due to current and future changes. Many indicators can be used for monitoring changes in treeline ecotones. Ecological indicators related to plants, such as growth forms or regeneration processes (seed production, seedling mortality, or survival rate), are generally those aspects mostly studied. As for soils, physical, chemical, and biological properties can be selected as indicators of soil quality in treeline ecotones, in relation to their sensitivity to disturbance or stress. Most physical indicators are quite static, whereas chemical, and to a greater degree, biological characteristics may be very dynamic (Table 1 ). Integrating indicators (such as decomposition) can be very helpful for a complete soil-monitoring scheme.

An example of a useful ecological indicator for erosion resulting from grazing on sandy and dry soil would be the evaluation of areas of bare soil. Erosion removes soil cover, including most of the carbon contained in the upper layer. Loss of soil cover leads to fragmented treeline ecotones where the accumulation of organic matter is very low or restricted to small patches. In addition, aboveground and belowground biodiversity are reduced by erosion. Ecosystem services like decomposition and nutrient supply or carbon sequestration are also reduced. In the best case, recommendations based on the evidence from soil indicators, as summarized in this paper, will be accepted and implemented by policy makers in order to preserve carbon stocks and prevent soil erosion, and to protect biodiversity in the treeline ecotone, including belowground, as this is a precondition for the preservation of aboveground biodiversity. 
Table 1. Soil properties as indicators in treeline ecotones. Highly dynamic, dynamic, static indicators: soil property change within days or weeks, years or decades, or centuries, respectively

\begin{tabular}{|c|c|c|c|}
\hline & Highly dynamic & Dynamic & Static \\
\hline \multicolumn{4}{|c|}{ Physical, chemical an biological indicators } \\
\hline \multirow[t]{3}{*}{ Physical } & Porosity & Area of bare soil & Texture \\
\hline & Temperature & Soil structure & Soil depth \\
\hline & Water content & & \\
\hline \multirow[t]{4}{*}{ Chemical } & Labile carbon & Total carbon (TC) & - \\
\hline & Mineral nutrients $(\mathrm{N}, \mathrm{P}, \mathrm{K})$ & Total organic carbon (TOC) & \\
\hline & $\mathrm{pH}$ & Total nitrogen (TN) & \\
\hline & & $\mathrm{C} / \mathrm{N}$ ratio & \\
\hline Biological & $\begin{array}{l}\text { Soil organisms: } \\
\text { - Microbial biomass, metabolism } \\
\text { and diversity } \\
\text { - Indicators of stress conditions } \\
\text { (microbial quotients) } \\
\text { - Enzyme activities } \\
\text { - Root rot pathogens } \\
\text { - Mycorrhiza }\end{array}$ & $\begin{array}{l}\text { Rooting: } \\
\text { - Depth } \\
\text { - Biomass of fine roots } \\
\text { - Architecture of roots }\end{array}$ & - \\
\hline \multicolumn{4}{|c|}{ Integrating indicators } \\
\hline Ecological & - & $\begin{array}{l}\text { Humus forms and soil structure } \\
\text { that result from the decomposition } \\
\text { process }\end{array}$ & - \\
\hline
\end{tabular}

\section{CASE STUDIES ON SOIL INDICATORS AT EUROPEAN TREELINES}

In order to assess the importance of soil properties as indicators of natural and anthropogenic impacts, 7 case studies performed at the treeline in similar mountain regions were selected from a collaboration among the following European countries: Romania, Bulgaria, the Czech Republic, Slovakia, and Italy. Table 2 reports details for each case study, such as climate, soil type, vegetation, and the specific indicators used.

\subsection{Romania (Case 1)}

In Romania, Badea et al. (2012) studied air pollution, bulk precipitation, throughfall, soil condition, and foliar nutrients, as well as forest health and growth, from 2006 to 2009 at a study site belonging to the Long-Term Ecological Research (LTER) network in the Bucegi Mountains. They ascertained that bulk precipitation was generally acidic. Therefore, rain could contribute to forest soil acidification with a possible negative effect on forest health. In fact, the $\mathrm{pH}$ of the soil solution was acidic ( $\mathrm{pH} 4.4$ to 4.8 ) in most of the studied sites. Concentrations of acidic ions such as sulfate were below critical limits in the bulk precipitation (CLRTAP 2004), but could have significant long-term cumulative effects on soils and forest vegetation, especially in the context of changing climate.

\subsection{Romania (Case 2)}

Similar research carried out in the Retezat Mountains showed that $>90 \%$ of rain events were acidic with $\mathrm{pH}$ values $<5.5$, contributing to the high acidity of soils (Bytnerowicz et al. 2005). Drought that occurred in the southern Carpathians between fall 2000 and summer 2002, and frequent acidic rainfalls, could have caused the observed decline in forest condition, results confirmed at a national level for the 1992 to 2010 period (Badea et al. 2013). The very strongly acidic character of upper soil horizons $(\mathrm{pH}$ 3.4 to 4.2 ) can be partially attributed to the atmospheric deposition of sulfate, nitrate, and ammonium. Although soil acidification is common for this type of geological material (schist), it is possible that longterm deposition could further increase soil acidity in the Retezat Mountains.

\subsection{Bulgaria}

The Beklemeto region in the Central Balkan Mountains (Bulgaria) is representative of the relatively small mountains of the Balkan Peninsula, which share a similar land use history, where the upper 
Table 2. Case studies: site characteristics of representative soils from different European countries. MAAT: mean annual air temperature, MAP: mean annual precipitation. Ranges are given for MAAT and MAP because of different altitudes. For definitions of soil type see IUSS Working Group WRB (2015)

\begin{tabular}{|c|c|c|c|c|c|c|c|c|}
\hline $\begin{array}{l}\text { Location } \\
\text { of study } \\
\text { sites }\end{array}$ & $\begin{array}{l}\text { Elevation } \\
\quad(\mathrm{m})\end{array}$ & $\begin{array}{l}\text { MAAT } \\
\left({ }^{\circ} \mathrm{C}\right)\end{array}$ & $\begin{array}{l}\text { MAP } \\
(\mathrm{mm})\end{array}$ & $\begin{array}{l}\text { Parent } \\
\text { material } \\
\text { chosen }\end{array}$ & Soil type & Tree cover & $\begin{array}{c}\text { Key } \\
\text { disturbance } \\
\text { drivers }\end{array}$ & $\begin{array}{l}\text { Indicators } \\
\text { and } \\
\text { rationale }\end{array}$ \\
\hline \multicolumn{9}{|c|}{ Czech Republic } \\
\hline $\begin{array}{l}\text { Giant } \\
\text { Mts }\end{array}$ & 1185 & $2.6-3.5$ & $1300-1414$ & Granite & Podzol, Histosol & $\begin{array}{l}\text { Norway } \\
\text { spruce }\end{array}$ & $\begin{array}{l}\mathrm{SO}_{2} \text { pollution, } \\
\text { acidic } \\
\text { precipitation }\end{array}$ & $\begin{array}{l}\text { Carbon content, } \\
\text { proportion of } \\
\text { fulvic and } \\
\text { humic acids }\end{array}$ \\
\hline \multicolumn{9}{|l|}{ Slovakia } \\
\hline $\begin{array}{l}\text { Tatra } \\
\text { Mts }\end{array}$ & $1150-1250$ & $3.4-4.7$ & $931-964$ & $\begin{array}{l}\text { Moraine } \\
\text { deposits }\end{array}$ & Dystric Cambisol & $\begin{array}{c}\text { Norway spruce, } \\
\text { larch }\end{array}$ & $\begin{array}{l}\text { Storm, fire, } \\
\text { land use } \\
\text { change }\end{array}$ & $\begin{array}{l}\text { Microbial biomass, } \\
\text { activity and } \\
\text { functional diversity }\end{array}$ \\
\hline \multicolumn{9}{|l|}{ Romania } \\
\hline $\begin{array}{l}\text { Bucegi } \\
\text { Mts }\end{array}$ & $930-1720$ & $2-6$ & $800-1200$ & $\begin{array}{l}\text { Conglomerate, } \\
\text { sandstone }\end{array}$ & $\begin{array}{c}\text { Dystric Cambisol, } \\
\text { Eutric Cambisol, } \\
\text { Entic Podzol }\end{array}$ & $\begin{array}{l}\text { Norway spruce, } \\
\text { silver fir, } \\
\text { European beech }\end{array}$ & $\begin{array}{c}\text { Acidic } \\
\text { precipitation }\end{array}$ & Soil pH \\
\hline $\begin{array}{l}\text { Retezat } \\
\text { Mts }\end{array}$ & $800-1600$ & $3-7$ & $1300-1600$ & Schist & $\begin{array}{l}\text { Dystric Cambisol, } \\
\text { Entic Podzol }\end{array}$ & $\begin{array}{l}\text { Norway spruce, } \\
\text { European beech }\end{array}$ & $\begin{array}{c}\text { Acidic } \\
\text { precipitation }\end{array}$ & Soil pH \\
\hline $\begin{array}{l}\text { Bulgaria } \\
\text { Central } \\
\text { Balkan } \\
\text { Mts }\end{array}$ & $1050-1500$ & 6.1 & 914 & Schist & Dystric Cambisol & $\begin{array}{l}\text { European beech, } \\
\text { Norway spruce }\end{array}$ & $\begin{array}{c}\text { Fires, forest } \\
\text { conversion, } \\
\text { land use change }\end{array}$ & $\begin{array}{l}\text { Carbon content, } \\
\text { soil } \mathrm{pH}\end{array}$ \\
\hline $\begin{array}{l}\text { Italy } \\
\text { Passo } \\
\text { Brocon, } \\
\text { Central-Eas } \\
\text { Alps }\end{array}$ & $\begin{array}{l}1700-2000 \\
\text { stern }\end{array}$ & 4.6 & 1286 & $\begin{array}{l}\text { Granite and } \\
\text { limestone }\end{array}$ & Leptic Phaeozem & $\begin{array}{c}\text { Norway spruce, } \\
\text { larch }\end{array}$ & $\begin{array}{c}\text { Pasture } \\
\text { abandonment }\end{array}$ & $\begin{array}{l}\text { Enzyme activity as } \\
\text { indicators for } \\
\text { microbial functional } \\
\text { diversity, disturb- } \\
\text { ances and stresses }\end{array}$ \\
\hline $\begin{array}{l}\text { Madonna } \\
\text { di } \\
\text { Campiglio }\end{array}$ & $1730-1855$ & 4.2 & 1148 & $\begin{array}{l}\text { Granite covered } \\
\text { by moraine } \\
\text { deposits }\end{array}$ & Umbrisol & $\begin{array}{c}\text { Norway spruce, } \\
\text { larch, } \\
\text { Cembra pine }\end{array}$ & $\begin{array}{l}\text { Pasture } \\
\text { abandonment, } \\
\text { ski resorts and } \\
\text { tourism }\end{array}$ & $\begin{array}{l}\text { Bacterial-fungal } \\
\text { community molecular } \\
\text { profiles shaped by } \\
\text { aspect, parent material, } \\
\text { and forest attributes }\end{array}$ \\
\hline
\end{tabular}

treeline is mainly formed by broadleaved forests. The treeline of the region is formed by 3 vegetation zones: broadleaved forests, areas of coniferous forests (plantations, natural), and a juniperus zone. In this casestudy site, the combined effects of land use and climate change on soil properties was investigated. In the study region, altitudinal migration due to climate are expected for beech and occasionally for conifers. Changes in vegetation cover affect soil properties due to warming, changes in precipitation, increased transpiration, and poorer drainage. Among soil physical-chemical parameters, the focus was on SOM. Previous land use affects the potential for carbon sequestration in forest areas. Pastures are characterized by high carbon stocks and a greater density of roots in the surface layers of the mineral soil, thus conversions of grasslands to forests has clear consequences (Guo \& Gifford 2002, Murty et al. 2002). Zhiyanski et al. (2008, 2016) and Zhiyanski \& Sokolovska (2009) showed that land use change has affected the content of soil organic carbon in mountain ecosystems in the Central Balkan Mountains. The effects were associated with a reduction in soil organic carbon stocks when pastures were afforested to increase the treeline zone $40 \mathrm{yr}$ ago. Nevertheless, a significant amount of carbon is stored in the forest floor, and thus the loss of soil is compensated. Zhiyanski et al. (2008) emphasized that the implementation of thinning activities in coniferous plantations is desirable to improve the microclimate conditions and the accumulation of carbon in the soil system. Results for other soil properties from the studied region showed variation in relation to forest tree vegetation (Doichinova \& Zhiyanski 2009). Two groups of ecosystems could be distinguished according to soil properties in treeline zones with similar climatic characteristics: (1) beech and spruce forests, and (2) Scots pine forests. Clay and silt textural fractions, soil $\mathrm{pH}$, and exchangeable 
Ca were higher under Scots pine, while the soil under beech and spruce was characterized by higher total organic carbon (TOC) stocks, total N, and exchangeable $\mathrm{Na}$, and lower $\mathrm{pH}$ (Zhiyanski et al. 2008). These differences could be related to differences in organic matter content caused by differences in forest vegetation and microclimate peculiarities of the sites. Soil physical-chemical properties and the SOM content could be used as composite indicators for assessing the effect of land use on soil systems and stability of ecosystems in treeline ecotones. The lower carbon content in the mineral soil under spruce plantations compared to that under natural beech forest is related to factors such as silvicultural practices and land use history. Overall, carbon stocks both on the forest floor and in soil were highest for the highland pasture, followed by the spruce plantation, while the beech forest and the pine plantation were characterized by comparatively lower carbon stocks. The conversion from natural pasture or beech forest to coniferous plantation in treeline ecotones of the Central Balkan Mountains has resulted in a decrease in TOC stock. Nevertheless, the large organic carbon storage in the forest floor in the spruce plantation compensates for the carbon leached out from the mineral soil after this land use change. In terms of stability, carbon sequestrated in the mineral soil is more desirable than carbon sequestrated on the forest floor, which is more vulnerable to decomposition following disturbances. Carbon stocks and SOM quality are very useful indicators for the detection of changes in mountain forests (Zhiyanski et al. 2008, Doichinova \& Zhiyanski 2009) and their mapping could be used as an effective approach to identifying changes in supply of regulating ecosystem services (Zhiyanski et al. 2017).

\subsection{Czech Republic}

The research in the north-eastern part of the Czech Republic was carried out in the Mumlavska Hora area in the Giant Mountains National Park. The treeline in the Giant Mountains is at around 1200 to $1400 \mathrm{~m}$ above sea level (a.s.l.) (Treml \& Chuman 2015), and the typical vegetation of the ecotone is represented by Norway spruce Picea abies intermixed with Vaccinium shrubs and graminoids communities. The forest stand of Norway spruce used for sampling was naturally established, and has been minimally influenced by forest management. The area was affected by a severe forest decline, which started $>35$ yr ago and was mostly caused by elevated levels of anthropogenic $\mathrm{SO}_{2}$ deposition (Kopáček \& Veselý
2005). Following the dieback of spruce trees, an increase in grass and shrub cover was observed. The aim of this study was to evaluate how this change in vegetation influences the amount and the quality of organic matter in the O horizon. The organic matter of Oa horizons was fractionated into humic and fulvic acids (HA and FA) to study differences related to the dominant ground vegetation, Vaccinium myrtillus, Deschampsia flexuosa, or Molinia caerulea. The results indicated that the dominant shrub or grass species could quantitatively influence the amount of carbon in organic horizons (organic $\mathrm{C}$ was higher under M. caerulea than under $V$. myrtillus). However, the humification rate was similar under all dominant plant species, probably because of a strong interaction with site condition, and differences appeared only in the quality of humic compounds. The proportion of fulvic and humic acids was in fact different according to vegetation type (a higher proportion of HA was found under M. caerulea). Regarding the importance of HA and FA in soil development, the findings suggest that, after a shift towards grass vegetation due to forest decline, major changes may be expected not only in the organic horizons, but also in the whole soil profile. Vegetation changes due to predicted climate change, probably leading to forest decline, could cause significant changes in quantitative and qualitative parameters of SOM. Thus, the quantity and quality of SOM in the organic layers are good indicators of changes in mountain forests (Bonifacio et al. 2008b).

\subsection{Slovakia}

Windthrow and fire belong to natural disturbances evoked by extreme climate events, such as strong wind, and extreme hot and dry periods, occurring as a consequence of ongoing climate changes. In 2004, forest stands near the treeline in the Tatra Mountains (Slovakia) were seriously damaged by strong wind and a part of this area was subsequently affected by fire. Four long-term research plots (intact reference forest, extracted windthrow, nonextracted windthrow, and extracted windthrow later affected by fire) were established in 2005 to monitor changes in the abiotic environment, including the soil microbial component. Based on the analysis of soil microbial biomass, activity, and structure of functional groups, Gömöryová et al. (2011) showed that several microbial community attributes assessed in windthrow areas appear suitable for the monitoring of long-term changes. In particular, 
catalase activity proved to be a useful indicator, as it exhibited clear interannual trends with low seasonal variability. N-mineralization also differed significantly among years, but varied considerably during the vegetation period. Richness and diversity of microbial functional groups, as determined by the Biolog assay (Garland \& Mills 1991), did not differ between plots, but unidirectional temporal shifts qualify them as indicators of long-term change. In contrast, basal respiration and microbial biomass differed primarily among plots with different management practices. Basal respiration varied considerably among seasons as well as among years. Microbial biomass did not exhibit seasonal fluctuations, and inter-annual variability was much lower compared to other soil characteristics. It therefore proved to be a sensitive indicator of environmental change in disturbed plots.

\subsection{Italy (Case 1)}

This case study is part of a larger research program on the effects of woody plant encroachment on soil organic carbon dynamics, and in general on soil properties, along a latitudinal gradient in Italy. In this case, woody plant species recolonization after pasture abandonment was studied in the Central-East Italian Alps, in Castello Tesino (Trento province, Italy). Three stages of the recolonization process were selected: (1) a current cow pasture with annual grasses, (2) a heather Calluna vulgaris (L.) Hull and Rhododendron hirsutum L. shrubland, and (3) a Norway spruce Picea abies (L.) H. Karst. and larch Larix decidua Mill. forest. Three soil sample replicates were collected from each stage at both $0-5$ and 5-15 cm depth intervals.

Two groups of soil indicators, chemical and biological, were used to describe the effect of the recolonization process: TOC and enzymatic activities of main soil nutrient cycles $(C, N, P, S)$. TOC is considered the best indicator of soil quality, as soil carbon content provides information about soil degradation and influences all soil functions. On the other hand, enzyme activities are used to describe microbial functional diversity, and express the microbial community response to disturbances and stresses (Aon et al. 2001, Sowerby et al. 2005, Trasar-Cepeda et al. 2008). Fluorimetric analyses (Marx et al. 2001) were performed in order to evaluate the activity of cellulase, chitinase, $\alpha$ - and $\beta$-glucosidase, phosphatase, sulfatase, and xylosidase. The synthetic enzymatic index (SEI) (Dumontet et al. 2001) was then esti- mated in order to highlight variation in the sum of enzyme activities at both depth intervals.

When considering the first step of recolonization (from pasture to shrubland), we observed an increase in TOC content of +74 and $+35 \%$ (calculated with respect to pasture for 0-5 and 5-15 cm, respectively). A similar trend was observed for the SEI (+38 and $+156 \%$ ). Then, from shrubland to forest, a general return to the original values of pasture was found both for TOC (+10 and $-3 \%)$ and for the sum of the enzyme activities ( -6 and $+18 \%$ ). When considering the enzyme specific activity (i.e. ratio of each enzyme activity to unit of total organic carbon), this increment was detected only in the upper intervals (+33 and $+6 \%$ ). A clear decrease in this ratio was observed for forest stand $(-69$, and $-58 \%$ with respect to pasture). A change in land use, in this case pasture abandonment accompanied by a new vegetation cover, induced the microbial community to increase its decomposition activity during the first step of recolonization. An equilibrium level was then reached when the mature forest condition was established. In particular, the increase in enzymatic activities, which encompasses the increase in TOC, could reflect a modified functional diversity of microbial processes induced by the release of diverse carbon substrates by the new colonizing plant cover (shrubs etc.).

\subsection{Italy (Case 2)}

The aim of the last study was to determine whether a number of given state factors are important in shaping both chemical and microbial properties of the soil at the treeline in the Alps. Organic matter content and its characteristics, dissolved organic matter (DOM) and its phenolic content, bacterial-fungal community molecular profiles, and microbial biomass carbon and nitrogen content were evaluated (Carletti et al. 2009). Since microbiological processes regulate soil ecology and biogeochemistry, microbial community structure can be used as a dynamic indicator of forest ecosystem status after timber harvesting, revealing changes in nutrient and energy flow patterns measured under different aspects, parent material, and forest attributes. Aspect was considered as a proxy variable of microclimatic features. This topographic factor influences local site microclimate, mainly because it determines the amount of received solar radiation, snowmelt timing, soil freezing and thawing, and even water retention capacity and soil nutrient cycling ( $\mathrm{C}$ and $\mathrm{N})$, as well as other ecosystem processes. 
In particular, parent material and forest coverage attributes were investigated in 6 Norway spruce $P$. abies forest sites located in the subalpine range of the eastern Italian Alps. Studying the relationships that stand age, site physical/topographic variables, and parent material have with soil carbon content and characteristics in mountain areas may be useful for predicting how environmental changes could affect soil carbon content and its accumulation. Stands were chosen so that they were consistent, as far as possible, with respect to elevation, macroclimatic, and dominant tree variables, while changing for parent material and aspect. The treeline was under pastoral use. In all sites, regeneration is natural and follows marginal cutting or canopy opening. Study areas were chosen according to local geological maps with different parent materials classified as acid, alkaline, and intermediate. For each parent material, A horizons of 2 sites were selected as north-facing and south-facing for a total of 6 sites. The geologic parent material had the strongest effect and was aspectdependent. Microclimate features also played a distinct role in defining both soil chemistry and microbial community composition. In contrast, the composition of the deeper humus layers $(\mathrm{OH}, \mathrm{A})$ was stable and similar within a spruce tree canopy class. The most important variables in the construction of the discriminating models were soil $\mathrm{pH}$, dissolved organic matter (DOM) content, and phenolic compounds. Bacterial communities appeared to be shaped first and foremost by the substratum, secondly by mountain slope orientation, and thirdly by forest stage, thus confirming the canonical discriminant analysis (CDA) model. Fungal communities indicated patterns guided strongly by $\mathrm{pH}$, such as the highly diverse community of the acid/north, in which evenness was higher and differences related to 4 successional stages of the forest (in increasing order: gap [open patch, free of standing trees], juvenile, aggregate [slender tress reaching canopy height], and mature) were less evident, and did not lead to emerging dominance at mature stages, as occurred instead in each of the southfacing forests (La Porta et al. 2014). Rarefaction curves indicate a trend of higher diversity (less saturating) in acid/north conditions, while more saturating covered communities occur in southern-facing and mild bedrock $\mathrm{pH}$ conditions. With regard to the 4 forest stand age categories, the classes Archaeorhizomycetes and Sordariomycetes, and the genus Archaeorhizomyces presented with significantly higher values in gap samples, compared to the aggregate samples. Juvenile and mature forest samples presented intermediate quantities.

\section{CONCLUSIONS}

The case studies reported in this paper present an example of how the use of soil indicators at the treeline can help to describe the intrinsic properties of these fragile ecosystems. In particular, soil indicators can act as an early warning of degradation processes, leading to critical thresholds of sustainability in response to diverse types of pressure (Muscolo et al. 2015). Furthermore, certain soil properties can be chosen as indicators of the resilience of treeline ecosystems in response to stress, and be included in monitoring actions within a soil policy framework. The above case studies confirm SOM as one of the significant universal indicators (Lal 2004). In particular, SOM content fluctuations can account for modifications of soil quality due to land use change from pasture to forest (Bulgaria and Italy), while SOM quality assessment (humification rate, humic/fulvic acids ratio, etc.) accounts for modification of soil carbon stocks induced by plant cover changes due to climate and/or land use change (Bulgaria, Czech Republic, Italy).

Bioindicators focusing on soil biota, such as microbial biomass size, diversity, and activity, can inform on changes in soil biogeochemical processes ( $\mathrm{C}$ or $\mathrm{N}$ cycling, mineralization, humification) and in food webs, or account for stress conditions (Slovakia, Italy). Moreover, due to their dynamic nature, bioindicators provide quick assessments of how the soil system reacts to the different pressures. This can help to prevent degradation processes by initiating correct policies and management strategies at the appropriate time.

In this study, several soil indicators were identified and used for the assessment of soil quality in relation to climatic and/or anthropogenic pressures in mountain forests. They were distinguished according to physical, chemical, and biological soil properties. Case studies in different mountain regions of Europe proved the importance of soil properties as indicators for the dynamics of mountain forest ecosystems and in the treeline ecotone in view of climate change and/or anthropogenic pressures. The case studies showed that SOM (in terms of quantity and quality), $\mathrm{pH}$, and microbial biomass size, activity, and structural and functional diversity are reliable and sensitive indicators to be recommended for monitoring changes in the soil system. However, beyond this basic set of properties (and when possible), it is advisable to integrate the information obtained by using supplementary indicators to gain further insight and for a more holistic approach to the study of the soil resource. 
Acknowledgements. This article is based upon work from COST ACTION ES 1203 SENSFOR, supported by COST (European Cooperation in Science and Technology, www.cost.eu).

\section{LITERATURE CITED}

Adhikari K, Hartemink AE (2016) Linking soils to ecosystem services - a global review. Geoderma 262:101-111

Anschlag K, Broll G, Holtmeier FK (2008) Mountain birch seedlings in the treeline ecotone, subarctic Finland: variation in above- and below-ground growth depending on microtopography. Arct Antarct Alp Res 40:609-616

Aon MA, Cabello MN, Sarea DE, Colaneri AC, Frenco MG, Burgos JL, Cortassa S (2001) I. Spatio-temporal patterns of soil microbial and enzymatic activities in an agricultural soil. Appl Soil Ecol 533:1-16

Arshad MA, Martin S (2002) Identifying critical limits for soil quality indicators in agro-ecosystems. Agric Ecosyst Environ 88:153-160

* Badea O, Bytnerowicz A, Silaghi D, Neagu S and others (2012) Status of the Southern Carpathian forests in the long-term ecological research network. Environ Monit Assess 184:7491-7515

Badea O, Silaghi D, Taut I, Neagu S, Leca S (2013) Forest monitoring - assessment, analysis and warning system for forest ecosystem status. Not Bot Horti Agrobo 41: 613-625

Becklin KM, Hertweck KL, Jumpponen A (2012) Host identity impacts rhizosphere fungal communities associated with three alpine plant species. Microb Ecol 63:682-693

Bjorbækmo MFM, Carlsen T, Brystig A, Vrålstad T and others (2010) High diversity of root associated fungi in both alpine and arctic Dryas octopetala. BMC Plant Biol 10: 244

Bonifacio E, Caimi A, Falsone G, Trofimov S, Zanini E, Godbold DL (2008a) Soil properties under Norway spruce differ in spruce dominated and mixed broadleaf forests of the Southern Taiga. Plant Soil 308:149-159

Bonifacio E, Santoni S, Cudlín P, Zanini E (2008b) Effect of dominant ground vegetation on soil organic matter quality in a declining mountain forest of central Europe. Bor Environ Res 13:113-120

Broll G (2000) Influence of overgrazing by reindeer on soil organic matter and soil microclimate of well-drained soils in the Finnish Subarctic. In: Lal R, Kimble JM, Stewart BA (eds) Global climate change and cold region ecosystems. Advances in soil science. CRC Press, Bosa Roca, p 163-172

Broll G, Keplin B (2005) Mountain ecosystems. Studies in treeline ecology. Springer, Berlin

Broll G, Jokinen M, Aradottir AL, Cudlín P and others (2016) Indicators of changes in the treeline ecotone. Deliverable 5, ESSEM COST ACTION ES1203-Enhancing the resilience capacity of sensitive mountain forest ecosystems under environmental change (SENSFOR). www. sensforcost.eu/index.php/deliverables

Buckeridge KM, Banerjee S, Siciliano SD, Grogan P (2013) The seasonal pattern of soil microbial community structure in mesic low arctic tundra. Soil Biol Biochem 65: 338-347

Bytnerowicz A, Badea O, Popescu F, Musselman R and others (2005) Air pollution, precipitation chemistry and forest health in the Retezat Mountains, Southern Carpathi- ans, Romania. Environ Pollut 137:546-567

* Carletti P, Vendramin E, Pizzeghello D, Concheri G, Zanella A, Nardi S, Squartini A (2009) Soil humic compounds and microbial communities in six spruce forests as function of parent material, slope aspect and stand age. Plant Soil 315:47-65

CLRTAP (Convention on Long-Range Transboundary Air Pollution) (2004) Manual on methodologies and criteria for modelling and mapping critical loads and levels and air pollution effects, risks and trends. Federal Environmental Agency, Berlin

Cotrufo MF, Soong JL, Horton AJ, Campbell EE, Haddix ML, Wall DH, Parton WJ (2015) Formation of soil organic matter via biochemical and physical pathways of litter mass loss. Nat Geosci 8:776-779

Doichinova V, Zhiyanski M (2009) Physical and chemical characteristics of forest soils from Beklemento regionCentral Stara Planina Mountains. Nauka za Gorata - For Sci 2:45-52

Doran JW, Parkin TB (1994) Defining and assessing soil quality. In: Doran JW, Coleman DC, Bezdicek DF, Stewart BA (eds) Defining soil quality for a sustainable environment. SSSA, Madison, WI, p 3-21

* Dumontet S, Mazzatura A, Casucci C, Perucci P (2001) Effectiveness of microbial indexes in discriminating interactive effects of tillage and crop rotations in a Vertic Ustorthens. Biol Fertil Soils 34:411-416

Egli M, Poulenard J (2017) Soils of mountainous landscapes. In: Richardson D, Castree N, Goodchild MF, Koboyashi A, Liu W, Marsten RA (eds) The international encyclopedia of geography. Wiley, New York, NY, p 1-10

Ekblad A, Wallander H, Godbold DL, Cruz C and others (2013) The production and turnover of extramatrical mycelium of ectomycorrhizal fungi in forest soils: role in carbon cycling. Plant Soil 366:1-27

Gardes M, Dahlberg A (1996) Mycorrhizal diversity in arctic and alpine tundra: an open question. New Phytol 133: $147-157$

Garland JL, Mills AL (1991) Classification and characterization of heterotrophic microbial communities on the basis of patterns of community-level sole-carbon-source utilization. Appl Environ Microbiol 57:2351-2359

* Gil-Sotres F, Trasar-Cepeda C, Leirós MC, Seoane S (2005) Different approaches to evaluating soil quality using biochemical properties. Soil Biol Biochem 37:877-887

Gömöryová E, Střelcová K, Fleischer P, Gömöry D (2011) Microbial characteristics at the monitoring plots on windthrow areas of the Tatra National Park (Slovakia): their assessment as environmental indicators. Environ Monit Assess 174:31-45

Guo LB, Gifford RM (2002) Soil carbon stocks and land use change: a meta analysis. Glob Change Biol 8:345-360

Haselwandter K (2007) Mycorrhiza in the alpine timberline ecotone: nutritional implications. In: Wieser G, Tausz M (eds) Trees at their upper limit. Plant ecophysiology, Vol 5. Springer, Dordrecht, p 57-66

Holtmeier FK (2009) Mountain timberlines. Ecology, patchiness, and dynamics, 2nd edn. Adv Global Change Res $36: 1-437$

*Holtmeier FK, Broll G (2005) Sensitivity and response of northern hemisphere altitudinal and polar treelines to environmental change at landscape and local scales. Glob Ecol Biogeogr 14:395-410

*Holtmeier FK, Broll G (2007) Treeline advance-driving processes and adverse factors. Landsc Online 1:1-33 
Holtmeier FK, Broll G (2010) Wind as an ecological agent at treelines in North America, the Alps, and the European Subarctic. Phys Geogr 31:203-233

IUSS Working Group WRB (2015) World reference base for soil resources 2014, update 2015. International soil classification system for naming soils and creating legends for soil maps. World Soil Resources Reports No. 106. FAO, Rome

Janvier C, Villeneuve F, Alabouvette C, Edel-Hermann V, Mateille T, Steinberg C (2007) Soil health through soil disease suppression: which strategy from descriptors to indicators? Soil Biol Biochem 39:1-23

Karliński L, Kieliszewska-Rokicka B (2004) Diversity of spruce ectomycorrhizal morphotypes in four mature forest stands in Poland. Dendrobiology (Pozn) 51:25-35

Karliński L, Rudawska M, Leski T, Kieliszewska-Rokicka B (2015) Biomass of external mycelium of ectomycorrhizal fungi in Norway spruce stands in Poland. Acta Mycol 50: 1063

Kernaghan G, Harper KA (2001) Community structure of ectomycorrhizal fungi across an alpine/subalpine ecotone. Ecography 24:181-188

Kopáček J, Veselý J (2005) Sulfur and nitrogen emissions in the Czech Republic and Slovakia from 1850 till 2000. Atmos Environ 39:2179-2188

Körner C (2012) Alpine treelines. Functional ecology of the global high elevation tree limits. Springer, Basel

Kyriazopoulos A, Abraham E, Hofgaard A, Sarki S (2014) DPSIR for treeline ecosystems and their services. Deliverable 3, ESSEM COST ACTION ES1203-Enhancing the resilience capacity of sensitive mountain forest ecosystems under environmental change (SENSFOR). www.sensforcost.eu/index.php/deliverables

La Porta N, Sablok G, Pindo M, Squartini A (2014) 454 pyrosequencing analyses of mountain forest soils reveal a high fungal diversity and a rapid response to successional stages. In: Parrotta JA, Moser CF, Scherzer AJ, Koerth NE, Lederle DR (eds) Sustaining forest, sustaining people: the role of research. XXIV IUFRO World Congress, 5-11 October 2014, Salt Lake City. International Forest Review 16(Spec Issue):166

Lal R (2004) Soil carbon sequestration impacts on global climate change and food security. Science 304:1623-1627

Marinari S, Bonifacio E, Moscatelli MC, Falsone G, Antisari LV, Vianello G (2013) Soil development and microbial functional diversity: proposal for a methodological approach. Geoderma 192:437-445

Marx MC, Wood M, Jarvis SC (2001) A microplate fluorimetric assay for the study of enzyme diversity in soils. Soil Biol Biochem 33:1633-1640

McBratney AB, Minasny B, Wheeler I, Malone BP (2012) Frameworks for digital soil assessment. In: Minasny B, Malone BP, McBratney AB (eds) Digital soil assessment and beyond. Taylor and Francis, London, p 9-14

* Moscatelli MC, Di Tizio A, Marinari S, Grego S (2007) Microbial indicators related to soil carbon in Mediterranean land use systems. Soil Tillage Res 97:51-59

Murty D, Kirschbaum MUF, McMurtrie RE, McGilvray H (2002) Does conversion of forest to agricultural land change soil carbon and nitrogen? A review of the literature. Glob Change Biol 8:105-123

Muscolo A, Settineri G, Attinà E (2015) Early warning indicators of changes in soil ecosystem functioning. Ecol Indic 48:542-549

Nannipieri P, Ascher J, Ceccherini MT, Landi L, Pietramel- lara G, Renella G (2003) Microbial diversity and soil functions. Eur J Soil Sci 54:655-670

Nielsen MN, Winding A (2002) Microorganisms as indicators of soil health. National Environmental Research Institute, Denmark. Technical Report No. 388

Oliver TH, Morecroft MD (2014) Interactions between climate change and land use change on biodiversity: attribution problems, risks, and opportunities. WIREs Clim Change 5:317-335

*Palombo C, Marchetti M, Tognetti R (2014) Mountain vegetation at risk: current perspectives and research needs. Plant Biosyst 148:35-41

Paz-Ferreiro J, Fu S (2016) Biological indices for soil quality evaluation: perspectives and limitations. Land Degrad Dev 27:14-25

Ponge JF (2013) Plant-soil feedbacks mediated by humus forms: a review. Soil Biol Biochem 57:1048-1060

Raev I, Zhelev P, Grozeva M, Markov I and others (2011) Programme of measures for adaptation of forests in Bulgaria and mitigate the negative impact of climate change on them. Project FUTUREforest helping Europe tackle climate change. INTERREG IVC, ERDF, Sofia

Reithmeier L, Kernaghan G (2013) Availability of ectomycorrhizal fungi to black spruce above the present treeline in Eastern Labrador. PLOS ONE 8:e77527

Ritz K, Black HIJ, Campbell CD, Harris JA, Wood C (2009) Selecting biological indicators for monitoring soils: a framework for balancing scientific and technical opinion to assist policy development. Ecol Indic 9:1212-1221

* Rovira P, Vallejo R (2002) Mineralization of carbon and nitrogen from plant debris, as affected by debris size and depth of burial. Soil Biol Biochem 34:327-339

Schmidt SK, Sobieniak-Wiseman LC, Kageyama SA, Halloy SRP, Schadt CW (2008) Mycorrhizal and dark-septate fungi in plant roots above 4270 meters elevation in the Andes and Rocky Mountains. Arct Antarct Alp Res 40: 576-583

Schmidt MWI, Torn MS, Abiven S, Dittmar T and others (2011) Persistence of soil organic matter as an ecosystem property. Nature 478:49-56

Sowerby A, Emmett B, Beier C, Tietema A and others (2005) Microbial community changes in heathland soil communities along a geographical gradient: interaction with climate changes manipulations. Soil Biol Biochem 37: 1805-1813

* Stanchi S, Falsone G, Bonifacio E (2015) Soil aggregation, erodibility, and erosion rates in mountain soils (NW Alps, Italy). Solid Earth 6:403-414

* Trasar-Cepeda C, Leirós MC, Gil-Sotres F (2008) Hydrolytic enzyme activities in agricultural and forest soils. Some implications for their use as indicators of soil quality. Soil Biol Biochem 40:2146-2155

* Treml V, Chuman T (2015) Ecotonal dynamics of the altitudinal forest limit are affected by terrain and vegetation structure variables: an example from the Sudetes Mountains in Central Europe. Arct Antarct Alp Res 47:133-146

*van Bruggen AHC, Semenov AM (2000) In search of biological indicators for soil health and disease suppression. Appl Soil Ecol 15:13-24

* Väre H, Vestberg M, Ohtonen R (1997) Shifts in mycorrhiza and microbial activity along an oroarctic altitudinal gradient in northern Fennoscandia. Arct Alp Res 29: 93-104

*von Lutzow M, Koegel-Knabner I, Ekschmitt K, Flessa H, Guggenberger G, Matzner E, Marschner B (2007) SOM 
fractionation methods: relevance to functional pools and to stabilization mechanisms. Soil Biol Biochem 39: 2183-2207

Wieser G, Holtmeier FK, Smith WK (2014) Treelines in a changing global environment. In: Tausz $\mathrm{M}$, Grulke N (eds) Trees in a changing environment. Springer, Dordrecht, p 221-263

Zhiyanski M, Sokolovska M (2009) Macro- and microelements in soils under spruce and beech forests in Central Stara Planina Mountain. Proc Seminar of Ecology, 23-24 April 2009, Sofia. Central Laboratory of General Ecology BAS, p 132-143

Editorial responsibility: Nils Chr. Stenseth, Oslo, Norway
Zhiyanski M, Kolev K, Sokolovska M, Hursthouse A (2008) Tree species effect on soils in Central Stara Planina Mountains. Nauka za Gorata - For Sci 4:65-82

Zhiyanski M, Gikov A, Nedkov S, Dimitrov P, Naydenova L (2016) Mapping carbon storage using land cover/land use data in the area of Beklemeto, Central Balkan. In: Koulov B, Zhelezov G (eds) Sustainable mountain regions: challenges and perspectives in Southwestern Europe. Springer, Basel, p 53-67

Zhiyanski M, Glushkova M, Kirova L, Filcheva E (2017) Quantitative and qualitative features of soil humus in mountain treeline ecosystems. Silva Balcanica 18:5-23

Submitted: April 8, 2016; Accepted: June 13, 2017 Proofs received from author(s): August 13, 2017 